\title{
MODEL PROJEK BASE LEARNING UNTUK MENINGKATKAN KREATIFITAS DALAM MATA KULIAH SEJARAH PENDIDIKAN
}

\author{
Zulfa, Kaksim, Juliandri Kurniawan Junaidi \\ Email:zulfaeva75@gmail.com, juliandry.junaidi@gmail.com, kaksim1983@gmail.com \\ Jurusan Sejarah STKIP Padang
}

\begin{abstract}
Abstrak
Mahasiswa kurang kreativ dalam mata kuliah Sejarah Pendidikan selama ini. mahasiswa cendrung mengerjakan project sesuai dengan yang mereka pahami. Kreativitas belajar mahasiswa dalam pembelajaran sejarah pendidikan masih tergolong rendah.Tujuan penelitian ini (1) untuk mengetahui aktivitas dosen dan mahasiswa terhadap materi sejarah Pendidikan zaman masa Islam melalui model Project Based Learning pada mahasiswa prodi pendidikan Sejarah STKIP PGRI Sumatera Barat. (2) Untuk mengetahui kreativitas belajar mahasiswa dengan melaksanakan model Project Based Learning pada mahasiswa 2017/A prodi pendidikan Sejarah. Penelitian ini menggunakan Penelitian Tindakan Kelas (PTK) yang meliputi empat tahap yaitu perencanaan, pelaksanaan, observasi dan refleksi. Subjek penelitian ini adalah mahasiswa berjumlah 48 orang. Hasil penelitian ini diperoleh rata-rata hasil observasi aktivitas dosen siklus I sebesar 64,21\% (cukup) mengalami peningkatan pada siklus II 77,89\% (baik) dan semakin meningkat pada siklus III 91,57\% (baik sekali). Hasil observasi aktivitas mahasiswa pada siklus I 63\% (cukup) dan mengalami peningkatan pada siklus II sebesar 77\% (baik) dan semakin meningkat pada siklus III 95\% (baik sekali). Sedangkan untuk kreativitas mahasiswa juga mengalami peningkatan, pada siklus I dengan persentase $62,54 \%$ (kreativitas sedang) dan mengalami peningkatan pada siklus II dengan persentase 68,66\% (kreativitas sedang) dan mengalami peningkatan pada siklus III dengan persentase $78,57 \%$ (kreativitas tinggi). Dengan demikian model Project Based Learning dapat meningkatkan kreativitas mahasiswa pada materi sejarah pendidikan zaman masa Islam pada mahasiswa 2017 Prodi Pendidikan Sejarah STKIP PGRI Sumatera Barat.
\end{abstract}

Kata Kunci: Project Based Learning, sejarah pendidikan, penelitian tindakan kelas.

\section{Pendahuluan}

Mata kuliah di program studi pendidikan sejarah cendrung bersifat ceramah. Hal ini sering terjadi pada setiap mata kuliah sejarah terutama mata kuliah sejarah pendidikan.Mata kuliah ini berisi tentang penyampaian materi tentang teori-teori dan hal-hal yang berkaitan dengan pengembangan pembelajaran bagi mahasiswadan dosen dalam ilmu pendidikan sangat penting. Mahasiswa memang lebih ditekankan memahami materi bahkan cenderung hafalan. Hal ini karena mereka memang di siapkan untuk menjadi seorang pendidik dan pengajar. Untuk dapat menumbuhkan penguasaan mahasiswa terhadap semua materi yang terkait dengan sejarah pendidikan, terlebih dulu mahasiswa harus mempunyai rasa tertarik terhadap materi yang mereka 
terima di kelas. Selama ini ada kecenderungan bahwa mahasiswa dalam pengerjaan tugas kurang kreatif dalam mengembangkan materi sejarah pendidikan. Mahasiswa hanya mengerjakan tugas sesuai dengan yang mereka ketahui sehingga tidak muncul kreativitasnya. Hal ini antara lain yang ada dalam pembelajaran sejarah pendidikan yang ditunjukan dengan kurangnya kreativnya mahasiswa selama mengikuti proses perkuliahan di kelas.

Model pembelajaran yang selalu ceramah akan menurunkan tingkat Kreativitas mahasiswa dalam pembuatan tugas maupun project. Mulai dari kreatif dalam mereka mengajukan pertanyaan, kreatif dalam diskusi, kreativitas dalam mengikuti perkuliahan, dan lainnya. Kecenderungan terhadap keaktifan dan semangat mahasiswa untuk mengikuti perkuliahan sangat penting, karena berkaitan dengan tingkat pemahaman dan penguasaan mahasiswa terhadap materi yang diterima. Sehingga mahasiswa tidak hanya pasif ketika mengikuti perkuliahan atau datang hanya untuk memenuhi persentase presensi. Tujuan penelitian ini adalah : (1) untuk mengetahui aktivitas dosen dan mahasiswa terhadap materi sejarah Pendidikan zaman masa Islam melalui model Project Based Learning pada mahasiswa prodi pendidikan Sejarah STKIP PGRI Sumatera Barat. (2) Untuk mengetahui kreativitas belajar mahasiswa dengan melaksanakan model Project Based Learning pada mahasiswa 2017/A prodi pendidikan Sejarah.

\section{Tinjauan Teori}

Mata kuliah sejarah Pendidikan adalah mata kuliah yang lebih banyak bersifat hafalan pembelajaran yang merupakan salah satu mata kuliah pengembangan bidang studi sejarah tematis pada program studi pendidikan Sejarah. Tujuan matakuliah adalah mengembangkan kemampuan pemahaman kritis mahasiswa terhadap fenomena upaya manusia dalam bidang pendidikan yang memiliki kontribusi terhadap pembangunan kebudayaan umat manusia dari

jaman ke jaman baik di Indonesia maupun di luar Indonesia, juga mengembangkan sikap kreatif dan inovatif mahasiswa dalam mengembangkan kesadaran pentingnya pendidikan dalam pembangunan masyarakat masa kini dan masa datang. Untuk itulah model Pembelajaran Project Based Learningsangat cocok dalam mata kuliah sejarah pendidikan ini.

\section{Model Pembelajaran Project Based Learning (PjBL)}


Pembelajaran PjBL adalah model pembelajaran yang memberikan kesempatan kepada dosen untuk mengelola pembelajaran di kelas dengan melibatkan kerja proyek. Melalui pembelajaran berbasis proyek, kreativitas dan motivasi mahasiswa akan meningkat. Kerja proyek dapat dipandang sebagai bentuk open-ended contextual activity-based learning, merupakan bagian dari proses pembelajaran yang memberi penekanan kuat pada pemecahan masalah sebagai suatu usaha kolaboratif yang dilakukan dalam proses pembelajaran pada priode tertentu.

Model pembelajaran PjBL merupakan model pembelajaran yang melibatkan mahasiswa dalam kegiatan pemecahan masalah dan memberi peluang mahasiswauntuk bekerja secara mandiri. Fokus pembelajaran terletak pada prinsip dan konsep inti dari suatu disiplin ilmu, melibatkan mahasiswa dalam pemecahan masalah dan kegiatan tugas-tugas bermakna yang lain, memberi kesempatan mahasiswa bekerja secara mandiri dalam mengkonstruksi pengetahuan mereka sendiri, dan mencapai keinginan untuk menghasilkan produk nyata.

Model PjBL adalah kerja proyek memuat tugas-tugas yang kompleks berdasarkan kepada pertanyaan dan permasalahan (problem) yang sangat menantang, menuntut mahasiswa untuk merancang, memecahkan masalah, membuat keputusan, melakukan kegiatan investigasi, serta memberikan kesempatan kepada mahasiswa untuk bekerja secara mandiri. Pembelajaran berbasis proyek juga merupakan model yang memusat pada prinsip dan konsep utama suatu disiplin, melibatkan mahasiswa dalam memecahkan masalah dan tugas penuh makna lainya, mendorong mahasiswa untuk bekerja mandiri, dan pada akhirnya menghasilkan karya nyata. Model pembelajaran berbasis proyek didefinisikan sebagi suatu pembelajaran yang mencoba mengaitkan antara teknologi dengan masalah kehidupan sehari-hari mahasiswa atau dengan suatu proyek sekolah. Pembelajaran berbasis proyek sebagi pendekatan pembelajaran yang melibatkan mahasiswa dalam suatu kegiatan penyelidikan. Mahasiswa melakukan sendiri penyelidikannya atau bersama kelompoknya sendri sehingga mahasiswa dapat mengembangkan keterampilan yang akan bermanfaat bagi pengembangan kemampuan mereka. Pembelajaran berbasis proyek dapat memusatkan diri terhadap adanya sejumlah masalah yang mampu memotivasi, serta mendorong para mahasiswa berhadapan langsung dengan konsep-konsep dan prinsip-prinsip pokok pengetahuan. Mahasiswa juga merasakan adanya masalah sendiri sebagai tantangan atau pertanyaan yang harus dijawab, serta dapat mengelola waktunya sendiri untuk dapat menyelesaikan proyeknya. Jadi, Pembelajaran PjBL merupakan pembelajaran yang menggunakan proyek/kegiatan sebagai media pembelajaran. Pembelajaran PjBL ini model 
belajar yang dosen hanya menjadi seorang fasilitator, dan mahasiswa diberikan kesempatan untuk melakukan pembelajaran yang menggunakan masalah sebagai langkah awal dalam mengumpulkan pengetahuan baru berdasarkan pengalamanya dalam beraktivitas secara nyata. Dosen tidak hanya sekedar mengajarkan terkaitdengan teorinya saja, karena jika mahasiswa belajar dari teori saja dan tanpa adanya praktek maka pengetahuan yang mahasiswa miliki hanya sesaat saja tidak akan tahan lama. Jadi model ini sangat cocok digunakan pada materi penghematan sumber energi, sebab pada materi ini mahasiswa dituntut untuk bisa menghasilkan sebuah proyek yang nyata sekreatif mungkin. Tujuannya adalah agar mahasiswa mempunyai kemandirian dan meningkatkan kreativitas mahasiswa dalam menyelesaikan tugas atau masalah yang dihadapinya.

\section{Langkah-Langkah Model Pembelajaran Project Based Learning (PjBL)}

Penerapan suatu model pembelajaran harus memperhatikan langkah-langkah yang tepat untuk menentukan keberhasilan suatu model pembelajaran yang digunakan, termasuk model pembelajaran berbasis proyek. Adapun langkah-langkah model pembelajaran berbasis proyek yaitu:

1. Penentuan proyek (start with the essensial question), pembelajaran dimulaidengan mengajukan pertanyaan terlebih dahulu yang dapat membuat mahasiswamelakukan suatu aktivitas. Topik yang diangkat harus relevan dan sesuaidengan dunia nyata mahasiswa.

2. Mendesain perencanaan proyek (design a plan for project), perencanaansuatu proyek dilakukan secara kolaboratif antara dosen dan mahasiswa.Perencanaan proyek ini berisi tentang aturan dalam membuat proyek,aktivitas yang akan dilakukan, serta alat dan bahan yang akan digunakanuntuk menyelesaikan proyek.

3. Menyusun jadwal (create a schedule), dosen dan mahasiswa secara kolaboratifmenyusun jadwal dalam menyelesaikan suatu proyek. Waktu penyelesaianproyek harus jelas, dan peserta didik diberi arahan untuk mengelola waktuyang ada. Kenudian peserta didik mencoba menggali sesuatu yang baru,akan tetapi dosen juga harus tetap mengingatkan apabila aktivitas pesertadidik melenceng dari tujuan proyek.

4. Mengawasi jalannya proyek (monitor the students and the progress of theproject), dosen memonitor aktivitas mahasiswa selama menyelesaikan proyekdengan cara memfasilitasi 
mahasiswa pada setiap prosesnya. Dengan kata lain,dosen berperan sebagai mentor bagi aktivitas peserta didik.

5. Menguji hasil (assess the outcome), penilaian dilakukan untuk membantudosen dalam mengukur ketercapaian standar, berperan dalam mengevaluasi kemajuan masing-masing peserta didik, memberi umpan balik tentangtingkat pemahaman yang sudah dicapai oleh peserta didik, serta membantudosen dalam menyusun strategi pembelajaran berikutnya. Penilaian produkdilakukan saat masing-masing kelompok mempresentasikan produknya didepan kelompok lain secara bergantian.

6. Mengevaluasi pengalaman (evaluate the experience), dosen dan mahasiswamelakukan refleksi pada akhir pembelajaran. Proses refleksi dapatdilakukan secara individu maupun kelompok.

Menurut Djehan Nur Mulyani langkah pembelajaran PjBL adalahMenentukan proyek yang akan dilakukan, Pada tahap ini dosen memberikan proyek kepada mahasiswa. Menentukan kerangka waktu, tahap ini merupakan tahap berapa lama proyek yang akan dilakukan. Merencanakan kegiatan apa yang akan dilakukan, Pada tahap ini dosen menjelaskan gambaran proses pembuatan proyek yang terkait dengan materi. Merencanakan penilaian, pada tahap ini dosen menuliskan beberapa tujuan penilain, merencanakan alat-alat peniaian apa saja yang akan digunakan. Memulai proses pembelajaran pada materi, tahap ini adalah tahap pengerjaan proyek yang sudah direncanakan di kelas. Gambaran akhir proses pembelajaran pada materi, Tahap ini merupakan hasil akhir dalam suatu forum khusus, yaitumendiskusikan atau menulis hal-hal yang penting dari proses pembelajaran.

Sutirman menyebutkan langkah-langkah pelaksanaan model PjBL dibagi menjadi beberapa tahap, yaitu tahap orientasi, desain, pelaksanaan, dan evaluasi.

1. Tahap orientasi adalah tahap menumbuhkan motivasi belajar mahasiswa dan penyampaian pertanyaan-pertanyaan penuntun.

2. Tahap desain yaitu tahap dimana mahasiswa menindaklanjuti pertanyaan penuntun dengan merancang proyek yang akan dibuat. Pada tahap ini juga disusun jadwal kegiatan untuk menyelesaikan proyek tersebut.

3. Tahap ketiga, adalah pelaksanaan yang merupakan kegiatan inti, yaitu mengerjakan proyek yang telah dirancang sebelumnya, sesuai dengan jadwal yang telah disusun. 
4. Tahap evaluasi merupakan upaya yang dilakukan untuk menilai proses kegiatandan hasil kerja proyek. Tahap evaluasi berguna sebagai umpan balik bagi dosen dalam merancang dan melaksanakan strategi pembelajaran. Selain bagi dosen berguna pula bagi mahasiswa untuk mengetahui efektivitas rencana dan proses kerja proyek yang dilakukan, serta mengukur sejauh mana kualitas produk yang dihasilkan.

Dari langkah-langkah di atas terdapat beberapa perbedaan namun tujuannyatetap sama, sama-sama membahas tentang pemberian pertanyaan yang dapat memotivasi mahasiswa untuk terlibat dalam belajar, kemudian mahasiswa membuat perencanaan proyek dengan bimbingan dosen. Langkah selanjutnya adalah menyusun jadwal, mahasiswa harus membuat jadwal pelaksanaan proyek yang disepakati bersama dosen serta mengajukan tahapan pengerjaan proyek. Setelah itu dosenmelakukan monitoring pelaksanaan proses. Selanjutnya adalah penilaian, penilaian proyek ini digunakan untuk mengetahui pemahaman, kemampuan mengaplikasikan, kemampuan melakukan penyelidikan, dan kemampuan menerapkan keterampilan membuat proyek atau karya. Langkah yang terakhir adalah evaluasi yang dimaksudkan untuk memberikan kesempatan pada mahasiswa. Sutirman, project bassed learning, scientic method, dalam melakukan refleksi pembelajaran yang dilakukan baik secara individual maupun kelompok. Jadi pada model pembelajaran ini sudah menunjukkan bahwa dengan penerapan model pembelajaran $\mathrm{PjBL}$ bisa membuat mahasiswa lebih aktif dan kreatif dalam menyusun sebuah produk yang nyata.

\section{Kelebihan dan Kelemahan Model Pembelajaran Project Based Learning(PjBL)}

\section{Kelebihan Model Pembelajaran PjBL}

Model pembelajaran PjBL ini sangat menguntungkan baik bagi dosen

maupunmahasiswa, model ini dapat meningkatkan minat mahasiswa dalam belajar dan mahasiswa tidak terfokus pada materinya saja, akan tetapi mahasiswa langsung dapat merangkai sebuah proyek. Adapun kelebihan dari PjBL adalah:

a. Menigkatkan motivasi, mahasiswa tekun dan berusaha keras dalammencapai proyek dan merasa bahwa belajar dalam proyek lebih menyenangkan dari pada komponen kurikulum lain. 
b. Meningkatkan kemampuan pemecahan masalah, dari berbagai sumber yang mendeskripsikan lingkungan belajar berbasis proyek membuat mahasiswamenjadi lebih aktif dan berhasil memecahkan masalah yang kompleks.

c. Meningkatkan kolaborasi, pentingnya kerja kelompok dalam proyek memerlukan mahasiswa mengembangkan dan mempraktikkan keterampilan komunikasi.

d. Meningkatkan keterampilan mengelola sumber, membuat alokasi waktu dan sumbersumber lain seperti perlengkapan untuk menyelesaikan tugas.

e. Mendorong peserta didik untuk mengembangkan dan mempraktikkanketerampilan komunikasi.

f. Menyediakan pengalaman belajar yang melibatkan peserta didik secarakompleks dan dirancang untuk berkembang sesuai dunia nyata.

g. Melibatkan para peserta didik untuk belajar mengambil informasi danmenunjukkan pengetahuan yang dimiliki, kemudian diimplementasikandengan dunia nyata.

h. Membuat suasana belajar menjadi menyenangkan, sehingga peserta didikmaupun pendidik menikmati proses pembelajaran.

Menurut Moursund yang dikutip oleh Wena keuntungan pembelajaran berbasis proyek adalah Meningkatkan motivasi, disini mahasiswa berusaha keras untuk belajar lebih mendalam dan mencari jawaban dalam menyelesaikan suatu proyek. Meningkatkan kemampuan memecahkan masalah, Lingkungan PjBL membuat mahasiswa lebih aktif dalam memecahkan masalah-masalah yang kompleks. Meningkatkan kemampuan studi pustaka, mahasiswa harus mampu memperoleh informasi secara cepat melalui sumber-sumber informasi sehingga dapat meningkatkan keterampilan mahasiswa untuk mencari dan mendapatkan informasi yang jelas. Meningkatkan kolaborasi, pentingnya kerja kelompok dalam pembuatan proyek agar mahasiswa dapat mengembangkan ketrampilan berkomunikasi. Serta meningkatkan keterampilan manajemen sumber daya.

\section{Kekurangan Model Pembelajaran PjBL}

Kekurangan model pembelajaran PjBL adalah:Memerlukan banyak waktu untuk menyelesaikan masalah, walaupun telah mengatur alokasi waktu yang cukup masih saja memerlukan waktu yang lebih banyak untuk pencapaian hasil yang maksimal. 
a. Membutuhkan biaya yang cukup banyak dalam pembuatan proyek, tetapi tergantung dengan proyek yang akan dibuat.

b. Banyaknya peralatan yang harus disediakan dalam pembuatan proyek.

c. Peserta didik yang memiliki kelemahan dalam percobaan dan pengumpulan informasi akan mengalami kesulitan.

d. Kondisi kelas agak sulit dikontrol dan mahasiswa mudah menjadi ribut saatpelaksanaan proyekUntuk mengatasi kekurangan dari pembelajaran berbasis proyek di atasseorang pendidik harus dapat mengatasi dengan cara memfasilitasi mahasiswa dalammenghadapi masalah, membatasi waktu mahasiswa dalam menyelesaikan proyek,menyediakan peralatan yang sederhana yang terdapat di lingkungan sekitar,menciptakan suasana pembelajaran yang menyenangkan sehingga mahasiswa merasanyaman dalam proses pembelajaran.

Dengan menerapkanmodel ini dapat membuat peserta didik mengalami proses pembelajaran yang lebihbermakna.Kreativitas memiliki rumusan yang berbeda-beda, sehingga menimbulkanbanyak pemahaman tentang kreativitas, namun pada dasarnya kreativitas itu salingterkait pada pribadi yang unik dan diiringi dengan dorongan positif kemudianmenggunakan cara-cara baru dalam melakukan kegiatan. Kreativitas sebagai “fourP's creativity: person, process, press, product. Pengertian itu menggambarkanbahwa kreativitas terkait dengan pribadi kreatif yang melibatkan proses kreatif, dandidukung oleh dorongan dari lingkungan akan menghasilkan produk kreatif. Kreativitas dari segi "pribadi" (person) menunjukkan pada potesi dayakreatif yang ada pada setiap pribadi.

Kreativitas sebagai suatu "proses" (process)dapat dirumuskan sebagai suatu bentuk pemikiran dimana individu berusahamenumbuhkan hubungan yang baru, mendapatkan jawaban, metode atau cara barumenghadapi masalah. Kreativitas sebagai "pendorong" (press) yang datang dari dirisendiri berupa hasrat dan motivasi yang kuat untuk berkreasi. Kreativitas dari segi“"hasil” (product) segala sesuatu yang diciptakan seseorang sebagai hasil darikeunikan pribadinya dalam interaksi dengan lingkungannya. Ciri-Ciri Kreativitas.

Ada 4 macam aspek-aspek pokok prilaku kreatif, sebagai berikut:

a. Elaboration (elaborasi) adalah kemampuan untuk memotong, mengembangkan atau membubuhi ide atau produk.

b. fluency (Kelancaran), adalah kemampuan untuk menghasilkan banyak gagasan. 
c. Flexibility (keluwesan) adalah kemampuan memikirkan ide yang beragam yaitu kemampuan untuk mencoba berbagai pendekatan dalam memcahkan masalah.

d. keaslian (originality), adalah kemampuan untuk menghasilkan ide-ide yang luar biasa yang tidak umum.

e. Rancangan Penelitian. Rancangan penelitian merupakan sebuah ancang-ancang yang akan dilakukan dalam kegiatan penelitian. Penelitian adalah upaya seseorang untuk mengumpulkan data dan informasi sebanyak mungkin, agar dapat menganalisis tentang seluk beluk permasalahan. Dalam hal, ini peneliti harus terlibat langsung dalam pengumpulan data dan infirmasi yang berkaitan dengan masalah yang diteliti.

Adapun dalam pelaksanaannya melalui tahapan-tahapan yang membentuk suatu siklus tahap-tahapan sebagai berikut:

\section{Perencanaan (Planning)}

Dalam tahap ini peneliti merencanakan kegiatan belajar mengajar. Adapun langkahlangkah perencanaannya yaitu:

a. Menentukan materi yang akan diajarkan.

b. Menyusun RPS untuk setiap siklus.

c. Menyiapkan model pembelajaran yaitu model Projetc Based Learning.

d. Membuat soal tes.

e. Membuat lembar kerja mahasiswa

f. Membuat instrumen pengamatan aktivitas dosen dan mahasiswa selama berlangsung proses tindakan pada masing-masing siklus.

\section{Tindakan (Action).}

Langkah kedua yang harus diperhatikan adalah tindakan. Tindakan ini dilakukan secara sadar dan terkontrol. Adapun langkah awal yang dilakukan pada penelitian ini adalah menentukan materi, selanjutnya menyusun RPSuntuk siklus I. Kemudian peneliti melakukan tindakan berupa kegiatan belajar mengajar yang disesuaikan dengan RPS siklus I. Setelah selesai dilakukan tindakan pada siklus I,peneliti mengadakan ujian di akhir pembelajaran dengan soal post-tes untuk mengetahui sejauh mana hasil dari tindakan pada siklus I. Lalu peneliti melakukan refleksi dan mengkaji kembali hasil pembelajaran tersebut dengan berkonsultasi bersama dosenSejarah Pendidikan yang bertindak sebagai pengamat jika sudah diketahui letak keberhasilan dan hambatan dari tindakan I yang baru selesai dilaksanakan, dan apabila 180 | Seminar Nasional Sejarah ke 4 Jurusan Pendidikan Sejarah Universitas Negeri Padang 
mahasiswa tidak mencapai ketuntasan belajar maka peneliti melanjudkan siklus II dengan merevisi kembalihambatan yang ditemukan pada siklus I. Hal ini berlanjut sampai siklus III.

\section{Pengamatan (Observation).}

Pada tahap ini pengamatan mengamati setiap kejadian yang berlangsung ketika proses pelaksanaan tindakan yang dilakukan oleh peneliti seperti mengamati aktivitas mahasiswa pada saat pembelajaran berlangsung dan bagaimana cara dosen (peneliti) mengelola kelas, sambil melakukan pengamatan inipengamat mengisi lembar aktivitas dosen dan mahasiswa pada proses kegiatan belajar mengajar.

\section{Refleksi (Reflecting).}

Refleksi adalah kegiatan untuk meningkatkan, merenungkan dan mengemukakan kembali apa yang terjadi pada siklus I untuk penyempurnaan pada siklus II. Dalam hal ini peneliti dan pengamat saling berdiskusi, para pengamat memberi masukan dan perubahan-perubahan yang diperlukan untuk siklus berikutnya. Peneliti mencatat semua saran/masukan para pengamat untuk tindakan yang sesuai dengan siklus berikutnya.

\section{A. Subjek Penelitian}

Adapun mahasiswa yang dipilih sebagai sabjek dalam penelitian ini adalah mahasiswaberjumlah sebanyak 48 orang, mahasiswalaki-laki berjumlah 22 orang dan mahasiswa perempuan berjumlah 26 orang. Alasan pemilihan angkatan 2016 ini adalah berdasarkan pada rendahnya penguasaan mahasiswa terhadap kemampuan melakukan tugas, kurangnya kreativitas mahasiswa pada saat pembelajaran dilakukan dan rendahnya partisipasi mahasiswa dalam kerja kelompok.Penelitian ini dilaksanakan di Prodi Pendidikan Sejarah STKIP PGRI Sumatera Barat.

\section{Instrumen Penelitian}

Sebelum melaksanakan penelitian di lapangan, peneliti terlebih dahulu menyiapkan instrumen-instrumen penelitian. Instrumen penelitian merupakan salah satu perangkat yang digunakan dalam mencari sebuah jawaban pada suatu penelitian. Berikut ini merupakan uraian satu persatu macam-macam instrumen yang digunakan oleh peneliti, antara lain:

1. Lembar Pengamatan (observasi) Aktivitas DosenLembaran pengamatan aktivitas dosen adalah lembar untuk memperoleh data tentang aktivitas dosen dalam mengelola pembelajaran dengan menerapkan model Project Based Learning. Pengisian lembar pengamatan dilakukan dengan membubuhkan tanda chek-list sesuai dengan gambaran yang diamati. Lembar pengamatan 
diberikan kepada pengamat untuk mengamati setiap kegiatan selama proses pembelajaran berlangsung. Lembar pengamatan digunakan untuk memperoleh data tentang kemampuan dosen dalam mengelola pembelajaran dengan penerapan model Project Based Learning.

2. Lembar Pengamatan (observasi) Aktivitas MahasiswaLembar pengamatan aktivitas mahasiswadigunakan untuk memperoleh data tentang aktivitas mahasiswa selama proses pembelajaran dengan penerapan model Project Based Learning. Lembaran ini berupa daftar chek-list yang terdiri dari beberapa item yang menyangkut pengamatan mahasiswa pada materi keterkaitan antara aktivitas manusia dengan Lembaga Pendidikan Islamdengan menerapkan model Project Based Learning. Pengamatan dilakukan oleh seorang teman sejawat untuk diisi sesuai dengan keadaan yang diamati di lapangan.

\section{Lembar Observasi kreativitas Mahasiswa}

Lembar observasi kreativitas mahasiswa digunakan untuk mengetahui kreativitas mahasiswa terhadap proses pembelajaran. Lembar observsi ini diisi oleh peneliti sendiri, adapun kreativitas yang diamati yaitu: keluesan, kelancaran, elaborasi dan keaslian dengan skor 1, 2, 3, dan 4 sesuai dengan lembar observasi.

\section{Teknik Pengumpulan Data}

Teknik pengumpulan data merupakan langkah yang strategi dalam penelitian, karena tujuan utama dari penelitian ini untuk mendapatkan data. Tanpa mengetahui teknik pengumpulan data, maka peneliti tidak mendapatkan data yang memenuhi standar data yang ditetapkan.2 Untuk memperoleh data dalam penelitian ini, penulis menggunakan teknik pengumpulan data berupa:1. Observasi (Pengamatan) 3. Tujuan observasi ini adalah untuk mengetahui kesesuaian antara perencanaan dengan pelaksanaan tindakan serta tingkat kreativitas belaja mahasiswa dengan penerapan model pembelajaran Project Based Learning pada sejarah pendidikan Lembaga Pendidikan Islam.

\section{Teknik Analisis Data}

Adapun data-data yang diperoleh selanjutnya akan dianalisis berdasarkan rumusan masalah penelitian, yaitu sebagai berikut:

1. Data Aktivitas Dosen

2. Data Aktivitas Mahasiswa

3. Data kreativitas Mahasiswa 


\section{H asil Penelitian}

Penelitian ini dilakuan pada semester ganjil 2018-2019, peneliti mendapatkan beberapa informasi dari data yang diperoleh. Data yang dikumpulkan dalam penelitian ini adalah lembar observasi, rubrik penilaian kreativitas dan tes akhir, berikut uraian dari beberapa siklusPenelitian yang telah dilakukan sampai pada siklus ketiga ini dibantu oleh seorang dosen rekan sejawat yang bertindak sebagai observasi dan berfungsi sebagai teman diskusi dalam tahap refleksi. Adapun hasilnya adalah sebagai berikut:

Tabel 1.Hasil PTK Siklus I, Siklus II, dan Siklus III

\begin{tabular}{|c|l|c|c|c|}
\hline No & $\begin{array}{c}\text { Aspek Penelitian } \\
\text { (Peningkatan } \\
\text { Kreativitas) }\end{array}$ & Siklus I & Siklus II & Siklus III \\
\cline { 3 - 5 } & $\begin{array}{l}\text { Perencanaan } \\
\text { Aktivitas dosen } \\
\text { mengelola } \\
\text { pembelajaran }\end{array}$ & 64,21 & \% & \% \\
\hline 2. & $\begin{array}{l}\text { Aktivitas } \\
\text { mahasiswa dalam } \\
\text { pembelajaran }\end{array}$ & 63 & 77,89 & 91,57 \\
\hline 3. & $\begin{array}{l}\text { Kreativitas } \\
\text { mahasiswa dengan } \\
\text { menggunakan PjBL }\end{array}$ & 62,54 & 68,66 & 78,57 \\
\hline
\end{tabular}

Sumber: Pengolahan Data sendiri

Berdasarkan tabel di atas dapat dipahami bahwa: Aktivitas dosen dalam mengelola pembelajaran dengan penerapan modelProject Basad Learning pada siklus I diperoleh dengan kategori cukup64,21, dalam tahap siklus I kemampuan dosen dalam mengelolapembelajaran masih banyak yang harus diperbaiki yaitu kemampuan dosendalam mengapersepsi pembelajaran, kemampuan dosen dalam membimbingmahasiswa mempresentasikan hasil kerjanya, lalu ditingkatkan lagi pada siklusII. Pada siklus II masih ada juga yang harus diperbaiki seperti dosen masihkurang dalam mengawasi mahasiswa sehingga masih ada mahasiswa yang jalan-jalandan ribut, akan tetapi pada siklus II mengalami peningkatan dengan kategoribaik 77,89. Sedangkan pada siklus III aktivitas dosen dalam prosespembelajaran sudah mulai menunjukkan hasil yang maksimal yaitu dosensudah mampu dalam mengapersepsi pembelajaran, sudah mampumembimbing mahasiswa mempresentasikan hasil kerjanya, serta dosen sudahmampu 
mengatasi mahasiswa yang jalan-jalan dan ribut. Sehingga pada siklus IIIini mendapat jumlah persentase 91,57 dengan kategori baik sekali.

Aktivitas mahasiswa dalam mengelola pembelajaran dengan penerapan modelProject Basad Learning pada siklus I diperoleh dengan kategori cukup 63.Dalam tahap siklus I kemampuan mahasiswa dalam mengelola pembelajaranmasih banyak yang harus diperbaiki yaitu mahasiswa kurang bisamengidentifikasikan masalah yang terkait dengan topik yang sedangdipelajari, mahasiswa juga masih kurang kerjasama dalam pembuatan proyek,serta mahasiswa belum bisa menetapkan waktu yang telah ditetapkan oleh dosen,sehingga ditingkatkan lagi pada siklus II. Pada siklus II masih ada juga yangharus diperbaiki seperti mahasiswa belum mampu dalam menarik kesimpulantentang materi macam-macam sumber energi dan mahasiswa juga belum percayadiri dalam mempresentasikan hasil diskusinya. Akan tetapi pada siklus II inisudah mengalami peningkatan dengan kategori baik 77. Sedangkan padasiklus III aktivitas Mahasiswa dalam proses pembelajaran sudah mulaimenunjukkan hasil yang maksimal yaitu selama kegiatan pembelajaranmahasiswa semakin aktif dan bersemangat dalam mengikuti prosespembelajaran. Hal ini dapat dilihat pada saat mereka mengerjakan proyektepat pada waktunya, sehingga mendapat jumlah persentase 95 dengankategori baik sekali.

Kreativitas mahasiswa dengan menggunakan model Project Based Learning padasiklus I nilai rata-rata persentase kreativitas adalah 62,54\%, dengan mahasiswayang mendapat nilai 60 ke atas ada 14 orang dari 21 mahasiswa, nilai ini termasukkedalam kategori kreativitas sedang. Pada siklus II nilai rata-ratapersentase kreativitas sudah terlihat peningkatan dari siklus I yaitu 68,66\%,dengan mahasiswa yang mendapat nilai 60 ke atas ada 18 orang dari 21 mahasiswa,tetapi nilai ini masih ternasuk kedalam kategori kreativitas sedang. Sedang kan pada siklus III nilai rata-rata persentase kreativitas mahasiswasangat meningkat yaitu 78,57\%, semua mahasiswa yang mendapatkan nilai 60 keatas. Nilai ini terhasuk ke dalam kategori kreativitas tinggi. Haltersebut menunjukkan bahwa kreativitas mahasiswa terhadap pembelajaran Sejarah Pendidikan dengan menggunakan model Project Based Learning sudah memuaskan.

\section{Pembahasan}

Hasil penelitian ini menunjukkan bahwa kemampuan mahasiswa dilihat dari model PjBL untuk menintkatkan kreativitas pada mata kuliah Sejarah Pendidikan di Program Studi Sejarah 
STKIP PGRI Sumatera Barat, meningkat cukup tinggi. Pada kemampuan membuat project terjadi peningkatan. Hasil aktivitas dosen siklus I sebesar 64,21\% (cukup) mengalami peningkatan pada siklus II 77,89\% (baik) dan semakin meningkat pada siklus III 91,57\% (baik sekali).

Hasil observasi aktivitas mahasiswa pada siklus I 63\% (cukup) dan mengalami peningkatan pada siklus II sebesar 77\% (baik) dan semakin meningkat pada siklus III 95\% (baik sekali).

Hasil kreativitas mahasiswa mengalami peningkatan, pada siklus I dengan persentase 62,54\% (kreativitas sedang) dan mengalami peningkatan pada siklus II dengan persentase 68,66\% (kreativitas sedang) dan mengalami peningkatan pada siklus III dengan persentase 78,57\% (kreativitas tinggi). Dengan demikian model Project Based Learning dapat meningkatkan kreativitas mahasiswa pada materi sejarah pendidikan zaman masa Islam pada mahasiswa 2016 Prodi Pendidikan Sejarah STKIP PGRI Sumatera Barat.

Peningkatan pemahaman mahasiswa tentang model PjBL pada mata kuliah Sejarah pendidikan masing-masing dilihat dari kemampuan mahasiswa membuat PjBL di Program Studi Sejarah Kebudayaan STKIP PGRI Sumatera Barat, menunjukkan bahwa: 1. Mahasiswa telah memanfaatkan waktunya dengan baik. 2. Mahasiswa dapat membuat project yang sederhana namun dapat diangkat menjadi project yang berkualitas. 3. Mahasiswa bertanggung jawab terhadap project yang telah dibuat sehingga timbul kreativitas mahasiswa. 4. Mahasiswa mengembangkan kreativitas dalam membuat project dan menyimpulkan serta kemudian berusaha membagi informasi yang telah didapat kepada orang lain.

\section{Simpulan:}

Hasil penelitian ini diperoleh rata-rata hasil observasi aktivitas dosen siklus I sebesar 64,21\% (cukup) mengalami peningkatan pada siklus II 77,89\% (baik) dan semakin meningkat pada siklus III 91,57\% (baik sekali). Hasil observasi aktivitas mahasiswa pada siklus I 63\% (cukup) dan mengalami peningkatan pada siklus II sebesar 77\% (baik) dan semakin meningkat pada siklus III 95\% (baik sekali). Sedangkan untuk kreativitas mahasiswa juga mengalami peningkatan, pada siklus I dengan persentase 62,54\% (kreativitas sedang) dan mengalami peningkatan pada siklus II dengan persentase 68,66\% (kreativitas sedang) dan mengalami peningkatan pada siklus III dengan persentase 78,57\% (kreativitas tinggi). 


\section{DAFTAR PUSTAKA}

Agung Iskandar. (2010). Meningkatkan Kreativitas Pembelajaran Bagi Dosen. Jakarta: Bestari Buana Murni.

Anas Sudjono. (2001). Pengantar Statistik Pendidikan. Jakarta: PT Raja Gravindo Persada. . (2011). Pengantar Evaluasi Pendidikan. Jakarta: Rajawali PERS.

Ali Mohammad. (2007). Ilmu dan Aplikasi Pendididkan. Jakarta: Imperial Bhakti Utama.

Campbell David (1986). Mengemukakan Kreativitas. Yogyakarta: Kanisius. Departemen Pendidikan dan Kebudayaan. (2002). Kamus Besar Bahasa Indonesia. Jakarta: Balai Pustaka.

Dimyati, dkk. (2013). Belajar dan Pembelajaran. Bandung: Rineka Cipta. Djehan Nur Hendyat Soetopo (2005). Pendidikan dan Pembelajaran. Malang: Universitas

Muhammadiyah, Istarani. (2012). 58 Model Pembelajaran Inovatif. Medan: Media Persada.

Kokom komalasari. (2011). Pembelajaran kontekstual. Bandung : Refika Aditama.

Made Wena. (2006). Strategi Pembelajaran Inovatif Kontemporer. Jakarta: Bumi Aksara.

Riyanti Yatim. (2010). Metodologi Penelitian. Surabaya: SIC.

Rusman. (2013). Model-Model Pembelajaran. Jakarta: Raja Grafindi Persada. Slameto. (2010). Belajar dan Faktor-Faktor yang Mempengaruhi. Jakarta: Rineka Cipta.

Sumardi Suryabrata. (2002). Metodelogi Penelitian. Jakarta: Raja Grafindo Persada. Sutirman, project bassed learning, scientic method, diakses pada tanggal 11 juli dari situs: http://staff. uny. ac. id/sites/default/files/132309687/project- based-learning. pdf, 2017.

Trianto. (2010). Model Pembelajaran Terpadu. Jakarta: Bumi Aksara, Surya 